\title{
NON SENSE?
}

\section{A Discourse Analysis of the Danish Upper Secondary School Reform 2005}

\author{
Katrin Hjort \\ Department of Philosophy, Education and Religious Studies \\ University of Southern Denmark \\ Campusvej 555230 Odense, Denmark \\ Tel: 004-6550-2830Ｅ-mail: katrinh@ifpr.sdu.dk
}

\begin{abstract}
The Danish upper secondary school was reformed in 2005. The reform had been anticipated for a long time. It was badly needed and much was expected of it but when the reform was implemented, many teachers experienced several of the new measures as irrational or even absurd. The new legislation didn't make sense but appeared extremely complicated and contradictionary. This article studies the school reform through the filter of discourse analysis. The reform represents an advanced version of liberal management and is construed as an alliance between 4 conflicting regimes of practice. Consequently the reform is very difficult to handle for the teachers and the school management. They are facing a lot of dilemmas and the issue of professional competence development is becoming crucial.
\end{abstract}

Keywords: Upper Secondary School, Educational Reforms, Discourse Analysis, Regimes of Practice, Advanced Liberal Management, Professionalization, Competence Development 


\section{Modernisation of the Danish Upper Secondary School}

When the new Danish secondary school reform took off in 2005, it was met with great expectations. One of the ambitions of the reform was to professionalise the teachers. They were expected to leave their roles as "private practitioners" in separate classrooms and learn to work together in teams. The creation of a higher degree of inter-disciplinarity or interplay between academic topics was a second wish, and a third intention was to train the pupils to actively participate in creation of new knowledge needed in a world in constant change. Coherence and holism were the code words. The reform furthermore included a number of new forms of evaluation to secure permanent competence and quality development in the upper secondary schools.

Today, after the first batch of pupils has completed the reformed programme, the evaluations are mixed. Along the way many teachers have experienced a great number of the reform measures as meaningless or even absurd, and the numbers of teachers reporting work-related stress are dramatically increasing. (Note 1 )

How does it come that the reform has been so difficult to handle - even for the majority of teachers with a positive attitude - and which demands to competence development of the professional teachers are placed on the agenda?

The article looks at the Danish upper secondary school reform from the perspective of discourse analysis and focuses in particular on the different regimes of evaluation practices contained in the reform. The purpose of the analysis is to demonstrate how 4 competing discourses - in different strategic alliances - have constructed the reform. As a whole they can be characterised as representing the phenomenon Nikolas Rose and Mitchell Dean (1999, 1999) label advanced liberal management, the subtle combination of self-evaluation and self-governance with centrally defined standards and objects. However, each of them is aiming to install its own logic and its own form of evaluation and governance. They imply very different forms of knowledge production, they mean very different power relations between pupils, teachers and management, and they contain very different subject positions to be adopted by the involved parties. In spite of this inconsistency they co-exist and have to be taken serious by the teachers and the school.

The empirical material in the analysis below is the many layers of governing documents (executive orders, guidelines, curricula, self-evaluation systems etc.) that have been drawn up in connection with the Act coming into force. (Note 2) The material has been analysed in the Danish inter-university research project, Gymnasiereform (Upper Secondary School Reform) 2005, supported by the Danish Research Council for Culture and Communication 2004-2008. (Note 3)

\section{Discourse and Discourse Analysis}

The concept of discourse designates the way language is used to talk about the world. Discourse analysis is the analysis of what can be spoken about and how - and what can not be spoken about/how one can not speak - within a certain discourse, for example political, economic or religious. British linguist Norman Fairclough (1992, 1995) defines a discourse 
as a representation of experiences from a certain perspective and his "critical discourse analysis" deals with how different discourses compete or make alliances in order to define reality in special ways - and try to exclude other ways of talking about the world. Discourse theoreticians Laclau \& Mouffe (1985) have to a high degree illuminated the discursive conflicts or battles about hegemony, supremacy or the power of definition, while Fairclough also stresses the creative and innovative aspects of linking discourses in alternative ways.

This article draws in particular on the political science version of discourse analysis as it is represented in Nikolas Rose's and Mitchell Dean's Foucault-inspired governmentality studies of societal changes in Great Britain in the 1980s and 90s (Rose a/b 1999, Dean 1999). The concept of regimes of practice is central in this context, because the concept links discourses - understood as special ways of using language - with special ways of acting, special practices or techniques, methods or technologies. Within a given discourse that represents a given world picture, some actions seem more obvious - legitimate or legal - than others, while on the other hand other actions are sidelined as unthinkable, impossible or unnatural meaningless actions or madness. This does not imply that these types of actions do not take place. Within the religious discourse represented by the Ten Commandments it is, for example, forbidden to lie, steal and kill. This does not mean that this type of action never takes place. It does mean that special efforts have to be made to legitimise the actions if they are to take place "in the name of God".

\section{Discourse Analysis and Social Constructionism}

From the point of view of metatheory, discourse analysis is most often placed within a post-structuralist or social constructionist scholarly paradigm. In this connection, discourse psychologist Kenneth Gergen (1999) distinguishes between social construktiVism and social construktioNism. Where constructivists such as Jean Piaget (1952) and social constructivists such as Jerome Bruner (1986) emphasise the way in which people actively construe the world through (social) actions, the central point within social constuctioNism is that the knowledge we have about the world is a social construction. With reference to Kant and the late Wittgenstein (1953/1995), social constructionism stresses the significance of language for knowledge creation. The world cannot be understood without concepts. The knowledge construed is never independent of the categories and types of reasoning involved in the process.

Social constructionism represents in this way an epistemological, not an ontological, position. It does not represent a statement about what the world, history, nature or the human beings are like in reality. As a programme it is anti- essentialist. It does not make statements about "the true state of the world". The interest is directed to the conditions for knowledge creation - how the version of reality that obtains the status of knowledge is socially construed. The criteria for what is recognized as knowledge and science are viewed as socially constituted and socially constituting - with significance for (the possibilities) for social action. This does not necessarily imply the assumption that the world only exists in human language or consciousness, nor the assumption that everything that exists is a social construction. Neither is does necessarily imply radical scientific relativism. Some kind of knowledge and science 
can be considered as more consistent and of a better quality than others but the quality criteria have to be reflected as contextually produced, historically and socio-culturally. Science is what is accepted in the scientific society. (Baudrillard1988)

Like many other theories placing themselves within a social constructionist paradigm, discourse analysis refers to a wide extent to Michel Foucault's understanding of the relation between knowledge and power (Foucault 1978/91, 1982). The production of a certain form of knowledge presupposes - reproduces and produces - certain power relations and vice versa. The establishment of certain power relations presupposes - reproduces and produces - certain forms of knowledge. As a starting point, therefore, power should not be exclusively seen as something repressive or oppressive that is practised top-down in centralised power hierarchies, but also as something productive that can develop horizontally in decentralised relations of different kinds. Different types of knowledge creation can take place in many different forms of social relations and open up the possibility of those involved being able to position themselves - and be positioned - as subjects in many different ways. It is the purpose of discourse analysis to uncover precisely how.

On the other hand, when it comes to the understanding of the relationship between speech acts and other kinds of acts, the various discourse analytical approaches differ a little from one another. Fairclough (1992) distinguishes between three levels: firstly, discourse understood as language; secondly, discursive practice understood as language use, speech acts or linguistic social interaction; and thirdly, "other social practice”, physical, material, virtual etc. Laclau \& Mouffe, on the contrary, do not wish to reserve the discourse concept to what has been rendered in language. To Laclau \& Mouffe a certain discourse not only implies a certain type of langue and language use, but also certain institutionalisations, certain ways in which, for example, education, health or war can be organised. It is, however, common to most of the positions in discourse analysis that they - in continuation of the post-structuralist point of departure - try to be non-deterministic in their understanding of the relation between words and practical action. Discourses do not determine the "practical practice", but legitimise some forms of practice rather than others. Compare the example of the Ten Commandments.

\section{Analysing Regimes of Practice}

Social constructionism can be understood as a metatheoretical policy statement, and discourse analysis as one or more suggestions for a theory about the social significance of language. The choice of school of discourse analysis is crucial when it comes to the choice of methods for concrete empirical analyses of, for example, education.

Critical discourse analysis, which Fairclough represents, draws in particular on the tools of language analysis or linguistics to analyse communication, including political communication, media or mass communication (Hjort ed. 1997). On the other hand, discourse psychology, of which Gergen is a representative, is interested in showing the way in which the meaning created in the concrete inter-personal interaction in a cultural community achieves significance for the construction of the individual self or the subjective identity with which the science of psychology traditionally has concerned itself. (Wetherell et al. 2001) 
The political science discourse analysis of which Rose and Dean are representatives directs particular attention at the more abstract description of the forms of control or "conduct of conduct" that establish themselves in different societies in different historical periods. Political science discourse analysis - in line with Laclau \& Mouffe's discourse theory - is a conflict theory and the central concept is governmentality or governmentalising of management. Together with Foucault, Rose and Dean emphasise that the present liberal or neo-liberal management rationality in developed modernity is built on neither sovereign nor disciplinary power but is characterized by functioning in freedom. Advanced liberal management practices presuppose that the single individual or the single organisation voluntarily engages in self-governing activities that on the other hand can be facilitated supported, formed and targeted - from the centre. Advanced liberal management thus represents a refined linking of different forms of decentralized and centralized management and it is these different forms of management that Rose and Dean wish to uncover through their analyses of regimes of practice.

Regimes of practice analysis offer an operationalizing of discourse theory in the form of an analytical strategy that can lead to the formulation of a number of concrete questions to be asked to empirical material. The method has been chosen here because the point of interest is to understand what forms of management the old and the new forms of evaluation in the Danish upper secondary school represent. The method has special explanatory powers when it comes to the analysis of general management strategies, while other (discourse analytical) methods or analytical strategies can advantageously contribute to illustrating how these strategies in everyday life are interpreted, negotiated and administered in different ways, for example by different teachers in different schools.

In Dean's definition, the establishment of a regime of practice presupposes:

- The construction of a special object to be observed.

- $\quad$ The construction of a special observation point from which observation is made.

- The construction of special methods or tools for obtaining knowledge about the object.

- The construction of special techniques for intervening in what seems problematic about the object.

A practice regime rests upon the diagnosis by special authorities of what is to be regarded as problems, and how these problems are to be explained and addressed. A practice regime also builds on special strategies for problem resolution and on special visions or utopias about what the problem-free state consists in. The development of a practice regime therefore implies the development of a special logic or rationality - a special mentality or subjectivity among those involved. The practice regime delimits what it is possible to regard as a matter of course or logical, and what positions it is possible to adopt... and thereby also marginalise what is not sensible, what is incomprehensible, unreasonable, impossible or meaningless. A description of a practice regime is, in continuation of this, a description of a coherent constellation of certain forms of knowledge, power relations and possible subject positions. 
The concrete questions to be asked to empirical material can be:

- What is being observed?

- Where is the point of view of the observation?

- How is the observation being conducted?

- Why is the observation being conducted?

The material to which these questions are being asked are, as mentioned, the many external and internal governing documents associated with the new Danish Upper Secondary School Act.

\section{The Upper Secondary School Reform Compressed and Complex}

Institutionally, the Danish upper secondary school today encompasses four different youth education programmes: the classical three-year general upper secondary school, the two-year higher preparatory examination, which replaced the special preparatory class for teacher training about forty years ago, the technical upper secondary school, and the commercial upper secondary school. The upper secondary school caters for about $60 \%$ of a youth cohort, the general upper secondary school being the largest with approximately $40 \%$ of the pupils. There are, however, great geographical differences in Denmark. In Frederiksberg in the middle of Copenhagen around $60 \%$ of a year group attend the general upper secondary school while in other parts of the country this figure is as low as $30 \%$ (www.emu.dk 2007-06-08).

In contrast to the other educational institutions in Denmark - the primary and lower secondary school, vocational education programmes and university studies - what characterises the general upper secondary school is that it has been largely untouched by reforms over the past 50 years, even though the intake at upper secondary level has risen from around $8 \%$ in the 1960s to around half of a youth cohort today. The reforms of the public institutions of the welfare state that in Denmark is termed "modernisation of the public sector" (decentralisation, inter-professional cooperation and new forms of performance management) have largely bypassed the Danish upper secondary school. (Hjort 2001, 2005) As a consequence of the late modernisation the reform was an extremely compressed process. Almost overnight the upper secondary schools have had to adapt to all the many changes that the other institutions have had several years to learn to handle, one after the other.

However, the Danish upper secondary school reform is not merely an extremely compressed process. It is also extremely complex. The Upper Secondary School Act was the result of a broad political agreement that included all the parties in the Danish Folketing (Parliament) with the exception of the left wing 'Enhedslisten'. But an examination of the preliminary political work for the reform reveals that it was construed as an alliance between two discourses - two different ways of talking about education - which may be described as the project discourse and the competence discourse, respectively (Bøje 2004, Hjort ed. 2008). The project discourse was primarily conducted by critical, engaged upper secondary school teachers who argued that the world is not divided into subjects and disciplines, and that 
group-based interdisciplinary project work, inter alia, is a relevant working method if students are to be equipped for future knowledge creation in a constantly changing world. The Confederation of Danish Industries - DI - which represents some of the most technologically and organisationally advanced Danish enterprises, headed the competence discourse. The competence discourse, arguing in line with the project discourse but with a different emphasis, spoke in favour of forms of work that could ensure that the pupils developed academic, general and personal competences with a view to strengthening the competitiveness of single individuals, Danish enterprises and the Danish nation in a globalised market.

The first phases of the birth of the reform were dominated by an alliance between the project and the competence discourses. However, during the period up to the adoption of the Act, this was confronted by another powerful alliance, namely between what can be termed the canon discourse and the results discourse. (Note 4)

The canon discourse may be viewed as representing a re-traditionalised movement, an attempt to maintain and develop the traditional content and forms of work of the upper secondary school. As an example the curricular requirements of the Danish language and literature course instruct the teachers to read a certain number of literary works from the national tradition. An instruction in detail that is quite unfamiliar to the didactic tradition in the Danish school system. (Note 5) The results discourse, the alliance partner of the canon discourse, which was supported by the broader Confederation of Danish Employers, sought greater effectiveness and efficiency, faster flow and better grades in the Danish education system. (Moos et al 2005). From 2007 the Danish upper secondary schools was transferred from public institutions to non-profit self-ownership, i.e. in principle they are to be operated as independent enterprises but financed by the state through a taximeter system of payment linked to the pupils’ study activity.

Figure 1. The four discourses in the Danish Upper Secondary School Reform 2005

\section{PROJECT DISCOURSE}

- Knowledge creation: Focus on interdisciplinary project-organised work with a view to strengthening the pupils' creativity and critical sense, their independence and ability to cooperate.

\section{CANON DISCOURSE:}

- Cultural values: Focus on enhancing the pupils' knowledge of traditional (especially national Danish) academic and cultural values with a view to increasing cohesion in Danish society.

\section{COMPETENCE DISCOURSE}

- Competitiveness: Focus on developing the pupils' academic, social and personal competences with a view to strengthening their ability to compete in a globalised market.

\section{RESULTS DISCOURSE}

- Measurable results: Focus on the pupils' grade average, completion percentage and transition frequency to higher education with a view to increasing educational effectiveness and efficiency. 
(Note 6)

The Danish upper secondary school reform cannot, however, be exclusively understood as a consequence of internal, national Danish political alliances. Supra-national or international (education) policy agendas have also left their mark. The competence discourse draws on the dominant discourse in the European Bologna Process that was initiated in 1999 and which aims at integrating or synchronizing the national education systems in Europe as regards grades, curricula, course descriptions (ECTS) and structure (www.ciriusonline.dk, www.uvm.dk, Hjort 2008). (Note 7) The results discourse corresponds to the discourse represented in the OECD's recommendation of new types of financial management of education programmes, the so-called accountability systems, where schools, managements and teachers receive payment in relation to, inter alia, the pupils' scores on national tests.( www.oecd.org, Rahbek Schou 2006, Hjort 2008) (Note 8)

\section{Four Evaluation Regimes}

The reform has led to Danish upper secondary teachers being stretched between at least four different discourses, each with its own understanding of the overall objective of the work of the upper secondary school. The picture is equally mixed when it comes to evaluation practice.

Together with the canon discourse, which represents the tradition in the general upper secondary school and that is still very much alive and active in the upper secondary school, evaluation means that the teachers give the pupils marks.

The attainment level of the individual pupils is evaluated by using continuous assessment marks, internal test marks and reports, if applicable. 2 (Emphasis added Katrin Hjort (kh))

STX Executive Order, chapter 11, section 111, subsection. 1

space

If the form of evaluation of the canon discourse is regarded as a regime of practice, then the pupils' academic attainment level is the object of observation.. The point of observation - the point of view of evaluation - is the teachers' and among the observation methods are assignments, tests and examinations. The standards or the values by which evaluation is conducted are the criteria for important academic knowledge defined in the teachers' internal collegiate communities, inter alia through education, external examiners, textbooks, ministerial guidelines drawn up by professionals, professional unions etc. Thus, as a point of departure the teachers have the authority to define what is to be regarded as the pupils' academic problems and the right to intervene, for example by criticising the pupils' work or making them complete extra work assignments. The ideal pupil is clever and hardworking, and the position as "the stupid and lazy" pupil is not to be aspired to. The aim of the evaluation system is to maintain an academic level, which also implies classification of the pupils in terms of further education and employment options. In general, the type of evaluation contained in this regime may be characterized as summative, diagnostic and asymmetrical.

Subsection.3 The result of the evaluation is to be discussed with the class or group and with 
the individual pupil and used for adjusting the progression and level of the teaching in relation to the pupils'academic capacity. (Emphasis added kh)

STX Executive Order, chapter 11, section 107

On the other hand, another evaluation regime dominates within the project discourse. Here it is not the pupils but the work, the study activities and learning processes that are the objects of observation, and both teachers and pupils are under observation. The method of evaluation is dialogue - i.e. a conversation that in principle is on equal terms - among the direct participants in the process. The authority to diagnose problems and propose model solutions or forms of intervention presupposes own experience but also the will to make one's own contribution. The standards on which the evaluation of knowledge development and forms of work ar are, similarly, negotiated standards. The overall criteria for success are broad: What have we discovered? What have we learned? How can we do it better next time?" Within this regime, the ideal characterisation of which is formative, dialogic and symmetrical evaluation. "The good pupil" is reflective and engaged. "The problem position" is the unengaged pupil - or teacher - who cannot be bothered to become involved in reflections about the way in which work organisation in the school can be improved so as to create even more knowledge and even more critical and creative pupils.

Figure 2. Four evaluation regimes in the Danish Upper Secondary School Reform 2005

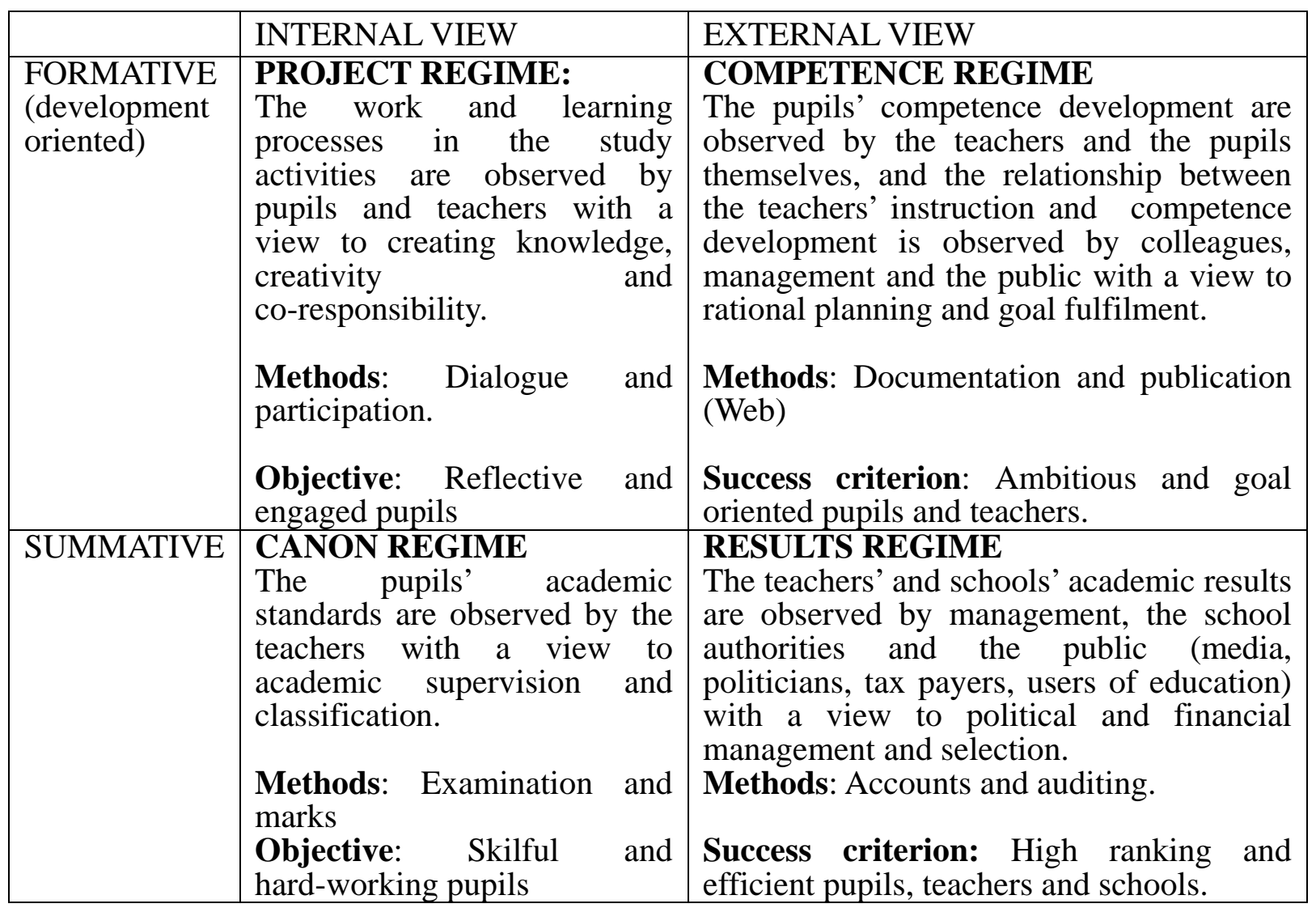

Both the canon discourse and the project discourse use the form of internal evaluation, in the sense that it is actors from within the school, teachers and pupils, who on the basis of their 
academic knowledge and experience make evaluative statements. With the competence discourse and the results discourse, an external view of the upper secondary school is installed. The reform of the upper secondary school makes evaluations a public matter. Instances with no direct access to the classroom - the pupils' parents, teachers' colleagues, schools' management, school authorities, media, politicians, coming users or consumers of the schools, including the employers that employ the pupils - are to have the possibility of observing and assessing the teaching and learning processes and their results. The new information and communication technology, including the schools' intranet and extranet, make this technically possible.

A new object of observation is construed with the evaluation regime of the competence discourse: the pupils' competences or rather their academic, general and personal competences. At the same time a new point of view is installed: the pupils' view of themselves. By means of the ongoing evaluation procedures - permanent self-reflection - the pupils are to form "a clear picture of their own strengths, weaknesses and progress". In other words, the competence regime opens the way for the development of what, in Foucaultian terms, could be regarded as the development of a new type of self-technology: the pupils' ability to take responsibility for and manage their own learning. The ideal pupil is ambitious and focused, and where problems are observed the possibilities for intervention are supervision or guidance of the individual so that the person in question can get back on the right track. The guidelines here are the objectives for academic knowledge, insight and method laid down in the curricula, i.e. the authority to decide what is progress or decline is non-negotiable. While the evaluation is formative and dialogic, the development-oriented dialogue does not take place in symmetrical relations.

Subsection 2. The plan is to ensure that there is ongoing evaluation of the individual pupil so that the pupil's academic, general and personal competences are evaluated and are developed.

Section 109. The ongoing evaluation is to ensure that the individual pupil has a clear picture of own strengths, weaknesses and progress and it is to form the basis for adjustments in the teaching.

Subsection 2. The evaluation is to form the basis for guidance of the individual pupil with respect to academic development and the development of working methods. (Emphasis added $\mathrm{kh})$

\section{STX Executive Order, chapter 11, section 107,109}

The competence discourse and the form of evaluation practice it implies are contradictory per se. On the one hand, it shares many of the project discourse's holistically formulated ideals: what is important is not that the pupils can reproduce already existing school knowledge, but that they can use this knowledge in the future outside of the school. For this reason the emphasis should not only be on cognitive aspects of learning and narrowly academic defined skills, here and now, but on "the whole person “i.e. on developing all the individual's intellectual, social and personal resources and potentials so that he/she creatively or 
innovatively can manage constantly changing challenges outside school in the future world. On this point the competence discourse can be in complete agreement with the project discourse in dissociating itself from the canon discourse's already fixed academic knowledge and cultural values. On the other hand, the competence discourse contains an extremely rationalistically formulated intention of being able to precisely define the objectives and targets to which the pupils' competence development should lead, and an ambition of precisely and linearly being able to plan and manage their learning processes. There are obvious points of alliance with the results discourse here.

Subsection 2. The term mark expresses the degree to which the individual pupil fulfils the objective for academic knowledge, insight and method in the curriculum in question and in relation to the stage at which the mark is given. Internal test marks express the degree of fulfilment of the objectives for academic knowledge, insight and method in relation to the assignments set. (Emphasis added kh)

STX Executive order, chapter 11, section111, subsection 2

The competence discourse's evaluation regime does not only cover the pupils' learning and competence development but also the teachers'. The ongoing evaluation is to be utilised as a basis for adjusting the teaching in order to achieve the desired teaching objectives. Here it is the teachers' planning and conduct of teaching that is the object of observation, and the methods are documentation in the form of the many syllabuses, course descriptions and evaluation plans that the teachers and schools are to draw up at local level and publicise on the web. In the first instance the authority to establish the criteria on which evaluation should be based and thus to define what is to be regarded as problems and solutions is assigned to the schools themselves.

The regulations in Executive Order no. 23 set out no specific method for self-evaluation or quality development, but they do set some general requirements that the methods chosen by the schools must live up to, while at the same time setting the requirement that the institutions must be able to document their quality systems vis-à-vis the Ministry of Education (...) The method and level of description with which the individual school chooses to work must thus serve a dual purpose. On the one hand, the system must be assured solid embedment in the school's culture, values and history, and thus be usable in practice on a day-to-day basis in order to serve as an effective instrument in the ongoing development of quality in the education and instruction provided. The system must not develop into a bureaucratic burden that hampers the administrative and teaching processes. On the other hand, the system must also be defined in sufficient depth to enable future students, course participants, employers, parents and other outside stakeholders to form an accurate impression of the school and its core activities, and thus compare it with corresponding schools.

Guidelines for Executive Order no. 23 of 11 January 2005 on "Quality development and performance assessment in upper secondary school education" January 2006 (Emphasis added kh)

In the next instance the evaluation regime of the results discourse clearly formulates the final 
success criteria for the schools" "performance":

Supervision is thus currently based on screenings of each institution's qualities, based on selected quality indicators:

- completion percentages

- $\quad$ marks average

- frequency with which graduates move on to higher education

Danish Ministry of Education's supervision plan 2006-2007. (Emphasis added kh)

In the results regime it is the schools' and teachers' results in the form of the pupils' performance that are observed by leaders, authorities and the political Öffentlichkeit. The observation methods are accountability and audit. What is explicitly looked for here is not "soft information gathered through dialogue between the ministry and institutions", (Note 9)but "operational quality objectives" (Note 10) or "concrete indicators for measuring quality.” (Note 11) The evaluations are to produce data that can be processed statistically with a view to benchmarking, i.e. ranking the schools in terms of quality and efficiency (for example the relation between average marks and teacher hours used). The successful school, the successful school management and the successful teacher is, in extension of this, placed highly with respect to results and has a low place in terms of consumption of public funds. The purpose of benchmarking is to provide coming pupils and their parents with consumer information and also to give the Ministry of Education the possibility of intervening and imposing sanctions, financial sanctions among others, if problems are diagnosed. The form of evaluation is summative, diagnostic and asymmetrical.

\section{Conclusion: Making Sense of The Non Sense?}

As a total complex, the 4 evaluation regimes in connection with the Danish upper secondary school reform represent a "textbook example" of what Rose and Dean term "advanced liberal management":

Advanced liberal practices of rule are"practices of liberty" in the sense that they continuously associate and dissociate the subjection and subjectification, dominance and fabrication of subjectivities. On the one hand they work by entering into contracts, consulting, negotiating and entering into partnerships, and even by authorizing and activating the types of ability to act, freedom and choice exercised by individuals, professional groups, households, neighbourhood associations and local societies. On the other hand they set the norms, standards, benchmarks, result indicators, quality controls and best practice criteria used to monitor, measure and make the performances of these agents calculable.

Mitchell Dean: Governmentality, 2006

When drawing up the many central governing documents associated with the reform, it has to a large extent been possible to link contradictory discourses in a creative fashion, as Norman Fairclough $(1992,1995)$ would have emphasised. Apparently it has to a high degree been possible to harmonize the contradictions when negotiating and writing on a political level. 
Never the less it might have been difficult, which is probably the reason for the governing documents being so extensive. (Note 12) If, however, with Laclau \& Mouffe one does not regard discourses as something purely linguistic but also as "institutionalisations" that lay down the framework for the legitimate organisation of task performance, it is obvious that the Danish upper secondary school reform must create problems in the implementation proces.

The linking together of different governmental strategies implies a great challenge for the teachers. On the one hand, these are precisely practices that only function in freedom, i.e. that presuppose the active engagement of the teachers. On the other hand, the task is extremely complicated because it means linkage of the discourses that, as a point of departure, are radically different and point in many different directions. In practice, the teachers, and the school management, must take into account many conflicting requirements and considerations:

The desire of the canon discourse to maintain or increase the academic level conflicts for example with the ambition of the results discourse for a swift flow of pupils with as high marks as possible. The intention of the project discourse concerning the pupils' collective co-responsibility for the work at school does not harmonise with the individualisation of the competence discourse. The basic assumption of the project discourse that knowledge creation presupposes independence and a critical approach to established truths conflicts with the endeavour of the competence discourse to establish final learning targets. And not least it conflicts with the requirements of the results discourse about measurable results. In its turn, the results discourse has a problem with the overall objectives formulation of the upper secondary school act concerning Bildung and Enlightenment, Citizenship and Democracy. Both the canon and the project discourses are very fond of these concepts but seen from the perspective of the results discourse the definitions of the concepts are vague and blurred and make it difficult to construe "objective indicators for goal fulfilment".

What is rational from the one angle does not make sense - or is even madness - from another”.

A second great challenge has been the logistics - organising the school's practice in time and space, individuals and work subjects. Different organisational principles have competed for the same limited physical and mental resources: classroom teaching in one subject with one teacher present as preferred by the canon discourse, the project discourse's multi-subject project work in groups, individual guidance of pupils as the competence discourse recommend, lectures in big halls and e-courses as rational within the results discourse etc. Each of these organisational principles has its rationality connected with the discourse within it is articulated but attempts to realise them at one and the same time have often had consequences that have seemed irrational by any measure. Ironically enough, this has led to attempts to manage the reform whose formulated intention has been to create unity and cohesion in the Danish upper secondary education programme by splitting it into increasingly smaller modules and building up increasingly more levels in the organisational hierarchy in order to coordinate them. (Note 13)

Consequently: There are good reasons for the initial feeling of confusion - the "sense of non sense" - and the present exhaustion among the teachers. The reform makes frequently 
conflicting or contradictionary demands on the Upper Secondary School and confronts the teachers and the management with constant ideological and practical dilemmas to handle in every day practice. Nevertheless, at the moment the task of the schools is to "make the whole thing work". All four discourses and the practice regimes they imply must be realised at one and the same time. The school staff has to make sense of the non sense. Those are the formal, official demands and the demands of daily life.

\section{Space}

\section{Perspectives: Professional Competence Development?}

Space

Working within a social constructionist framework of understanding makes it necessary to make explicit the perspective applied when approaching, evaluating and discussing an educational reform as the reform of the Danish upper secondary school. The reform and the governance practices it implies can appear very different according to the point of view and value basis selected. Is the interest directed at the pupils' learning processes? Towards knowledge development in specific subjects? Towards efficient financial management etc.?

The focus in this final discussion is the question of professional competence development among the teachers. In the beginning of the reform process most of the teachers and the trade unionists had a very optimistic view on the reform. The reform was seen as a new possibility for professional development, defined in the terms of increased knowledge, room for manoeuvre and social legitimacy. (Abbott 1981, Freidson 2001, Hjort ed. 2004). Later in the reform process as the consequences of the results discourse became more visible, the ambivalences grew. The reform was more explicit discussed as a possible threat to the teachers' professionalism. Did the reform imply the risk of de-professionalization, and how could the teachers deal with these threats? Which new kinds of competence development are required, if the teachers want to maintain, sustain, renew and expand their professional competence?

Especially the kind of practices linked to the project and he competence discourse has been seen as a possibility for new knowledge creation among the teachers (and the students). The inter- disciplinarity and cross- curricular activities contain the possibility of linking together the individual teacher's own subject knowledge with others, and the teachers' teamwork contains the possibility to share teaching experiences and evolve new ideas. The chance at last to modernise the rather conservative Danish upper secondary school and adapt it to the needs of modern youth looks like an obvious precondition for preserving the social legitimacy of the schools.

However, the risk of simultaneous de-professionalization emerged. Especially the results discourse is at stake here. The knowledge monopoly of the teachers is challenged by the political demands for evidence based teaching, best practices and calculations of economic efficiency, i.e. types of knowledge normally produced not by the teachers themselves but by school external actors, researchers, private consultancy firms etc. The relative autonomy of the teachers is restricted as well, if the new knowledge are going to dictate the teachers practice instead of informing there professional decisions. Finally, the legitimacy of the upper secondary schools as public schools is under pressure. Traditionally the Danish schools and 
the teachers have been an integrated part of the classic Nordic Welfare State constructions. Committed to and legitimized by the universalistic democratic ethos:"The best possible education for all”. Today it becomes more and more obvious that if the schools want to secure their own financial survival on the new commercialized conditions they have to compete with their neighbours in order to capture "All the best possible students".

This situation calls for a new kind of professionalization of the upper secondary school teachers. The Danish upper secondary teachers do already have an academic degree but a new professional competence development might include academizing within a number of new areas:

- The new cross-curricular activities and the interplay between subjects call for meta-theoretical considerations, theory of science and methodological reflections.

- The new cooperative teaching and learning practices call for "a common language" in the shape of pedagogical and didactical knowledge and skills in order to de-privatize and reflect on what traditionally is referred to as tacit knowledge. (Polanyi 1966)

- The new organisational challenges linked to the decentralisation and marketizing of the schools calls for more education within (public) organisation and management. Not only for the top management and the new crew of middle management but for all the staff involved in the permanent construction and re-construction of the school organisation.

The most crucial discussion however might be how to revitalise, reconsider and recreate professional ethics or democratic legitimacy of the teachers and the schools.

\section{Acknowledgement}

The research has been supported by the Danish Research Council for Culture and Communication 2004-2008.

\section{References}

Abbott, A. (1981). Status and Status Strains in the Professions. The American Journal of Sociology, 86(4), 819-835

Aili, Carola, Lars-Erik Nilsson, Lennart G. Svensson \& Panela Denicola (eds) (2007): In Tension between Organization and Profession -Professionals in Nordic Public Service. Lund: Nordic Academic Press

Baudrillard, J. (1988). Simulacra and Simulations. J. Baudrillard, Selected Writings, ed. Mark Poster .Stanford: Stanford University Press, 166-184

Bøje, J. (2004). Modernisering af projektarbejdet? En historie om projektarbejdets status i den nye gymnasiereform og i gymnasieskolens praksis. Kandidatspeciale, Institut for Uddannelsesforskning RUC. [Modernization of the project work. Masterthesis, Roskilde University]

Bruner, J. (1986). Actual Minds, Possible Worlds. London: Harvard University Press

Dean, M. (1999). Governmentality. London: Sage Publications 
Fairclough, N. (1992). Discourse and Social Change. Cambridge: Polity Press

Fairclough, N. (1995). Critical Discourse Analysis: The Critical Study of Language. London: Longman

Foucault, M. (1978/91). Governmentality. G. Buckell, C. Gordon \& P. Miller. The Foucault Effect. Studies in Governmentality.Chicago: The University of Chicago Press. 87-104

Foucault. M. (1992). Afterword. The Subject and Power. H. K. Dreyfus \& P. Rabinov (ed.) Michel Foucault. Beynd Structuralism and Hermeneutics. Chicago: The University of Chicago Press 208-226

Friedsson, E. (2001). Professionalism: The Third Logic. Cambridge: University of Chicago Press

Gergen, K. J. (1999). An Invitation to Social Construction. London: Sage

Hjort, K. (2001). Moderniseringen i den offentlige sektor. [Modernizing of the Public Sector] København: Roskilde Universitetsforlag

Hjort, K. (2005). Professionaliseringen i den offentlige sektor. [Professionalizing in the Public Sector] København: Roskilde Universitetsforlag

Hjort, K. (2008). Demokratiseringen i den offentlige sektor. [Demokratization in the Public Sector] København: Roskilde Universitetsforlag

Hjort, K. (ed) (2008): Gymnasiereform 2005 - professionalisering af ledere, larere og elever?[Upper Secondary School Reform 200] University of Southern Denmark: Gymnasiepædagogik

Hjort, K. (ed.) (2004). De Professionelle - forskning i professioner og professionsuddannelser [The Professionals - research in professions and Education of professionals]. København: Roskilde Universitetsforlag

Hjort, K. ed. (1997). Diskurs - Analyser af tekst og kontekst, [Discourse - Analyses of Text and Context] København.: Samfundslitteratur

Laclau, E. \& Mouffe, C. (1985). Hegemony \& Socialist Strategy -Towards a Radical Democratic Politics. London: Verso

Moos, L., K. Braad, K. Hjort, J. Krejsler \& P. F. Laursen (2005). Evidens i Uddannelse? [Evidence in Education] København: Danmarks Pædagogiske Universitetsforlag

Piaget, Jean (1952). The Origins of Intelligence in Children. New York: International Universities Press, Inc.

Polanyi, M (1966). The Tacit Dimension, USA: Doubleday

Rahbek Schou, L. (2006) Standards and Accountability. Paper presented at the NERA Congress Ôrebro, Sverige

Rose, N. (1999 a). Governing the Soul - the shaping of the private self. London/New York: 
Free Association Books

Rose, N. (1999 b). Powers of Freedom - Reframing political thought. Cambridge: Cambridge University Press

Whetherell, M.; Tylor. S., and S. J. Yates (ed): Discourse Theory and Practice. London: Sage

Wittgenstein, L. (1953/1995). Filosofiske Undersøgelser. København: Munksgaard

www.bologna.dk 8.03.2007

www.ciriusonline.dk 8.03.2007

www.emu.dk 06.08.2007

www.oecd.org/dataoecd/56/42/34904246.pdf 06.02.2008

www.uvm.dk 8.03.2007

\section{Appendix}

Governing documents related to the reform of the Danish Upper Secondary School 2005 TIGHT-LOOSE-TIGHT or

\section{CENTRALISATION-DECENTRALISATION-RECENTRALISATION}

TIGHT - key political governing documents

- 1) Agreement document: the political agreement of 28 May 2003 regarding the reform of upper secondary education

- $\quad 2$ 2) Act no. 95 on Education for the Upper Secondary School Leaving Examination of 18 February 2004 (STX Act). (Act still in effect, but amended on 24 June 2005 and 9 June 2006)

- 3) Executive Order no. 1348 on Education for the Upper Secondary School Leaving Examination (STX Executive Order) of 15 December 2004. (The executive order currently in effect is no. 825 of 17 July 2006). Contains curricula for the subjects and for the multi-subject coursework, general language comprehension and the natural science basic course, including setting of academic goals,

- 4) Guidelines for Executive Order no. 825 of 17 July 2006 on Education for the Upper Secondary School Leaving Examination, August 2006. Contains proposals for establishing competence goals, progression in use of working methods and product requirements,

LOOSE - governing documents that are to be drawn up at local level

- Teacher level:

o Curricula

o Course descriptions

o Evaluation plans

- Pupil level

o Study reports 
- Management level

o Systems for self-evaluation, quality development and performance assessment

o Follow-up plans - written plans that are to be drawn up at least once every third year as action plans that follow self-evaluation.

0

TIGHT - re-centralisation by means of political governing procedures

- 5) Act no. 414 of 6 June 2002 on transparency and openness in education (publication of marks on website)

- 6) Executive Order no. 23 of 11 January 2005 on quality development and performance assessment in upper secondary school education

- 7) Act no. 880 of 19 September 2005 on amendments to the Act on transparency and openness in education, etc. (publication of completion and employment percentages, etc),

- 8) Guidelines for Executive Order 23 of 11 January 2005 on quality development and performance assessment in upper secondary school education January 2006

- 9) 9inistry of Education's supervision plan 2006-2007 (7 November 2006)

- 10) Ministry of Education's sanctioning policy (7 November 2006).

\section{Notes}

Note 1 . In the research project $86 \%$ of the teachers report a more heavy work load, $49 \%$ report stress-symptoms as headache, palpitation, sadness and insomnia and $86 \%$ report less time for solving their tasks (2008). Compared with other reform processes in the Danish public sector (i.e. The Reform of The Municipal Structure 2007) these figures are remarkable.

Note 2. A very extensive series of governing documents are involved in the Danish upper secondary school reform, a total of 16 layers (cf. the list in the appendix). The documents are divided into three: central governing documents, including the Upper Secondary School Act that was adopted by the Danish parliament (Folketing) in 2004 and applies to all upper secondary schools; decentralised governing documents including curricula and evaluation plans, which are to be formulated locally at the individual schools; and finally the most recent key documents including the Danish Ministry of Education's plans for supervision and sanctions policy from 2006/2007. The documents represent a tight-loose-tight movement from central legal requirements over local governance and self-evaluation and back to central registration and control.

Note 3. "Upper Secondary School Reform 2005" is an inter-university Danish research project based on a three-year grant from the Danish Research Council for the Humanities (now the Danish Research Council for Culture and Communication) to monitor the implementation of the new Danish upper secondary school reform from the perspective of "Professionalising of management, teachers and students." The participants are Ph.D. fellow Jakob Ditlev Bøje, Department of Media, Understanding and Communication, School of Education, University of Copenhagen; Asst. Prof. Lene Larsen, Department of Psychology and Educational Research, Roskilde University; Assoc. Prof. Peter Henrik Raae, Department of Philosophy, Education and Rhetoric, The University of Southern Denmark; and Research Director, Katrin Hjort, professor, Department of Philosophy, Education and Rhetoric, The 
University of Southern Denmark.

Note 4. Jacob Ditlev Bøje has shown the way in which the alliance between the canon discourse and the results discourse manifested itself in the reform debate after the alliance between project and competence discourse had been the dominant discourse for some time. The movement took place in the course of winter 2003/2004, i.e. during the period between the drawing up of the political agreement paper between the parties to the reform and the adoption of the Act in February 2004 and the Executive Order of December 2004. (Bøje 2004)

Note 5. Interestingly enough, the curriculum for the subject of Danish also contains a subsidiary formulation. When the pupils have been through the core material in the area of literature in the form of a series of excursions into epochs, genres, and topics in literary theory and cultural history, in future Danish upper secondary pupils must familiarise themselves with 13 male authors plus Karen Blixen.

Note 6. The project and competence discourse is in particular represented - and integrated - in the preamble to the Upper Secondary School Act. The project and canon discourses are at odds in the guidelines for the individual subjects, cf., note 9. The competence discourse finds clear expression in the Executive Order's curricula and in the proposals in the guidelines for setting up competence targets, progression in the application of forms of work and product requirements, i.e. in the recommendations concerning the syllabuses and subsequent course descriptions that the teachers themselves have to write. The results discourse turns up in the Act that was adopted in 2005 on amending the Act on transparency and openness in the study programmes. However, it only becomes clear in the ministry's supervision plan and sanctions policy, which are the last of the central documents associated with the reform. (2006/2007)

Note 7. Denmark has not yet established a connection between the senior classes of the primary and lower secondary school $\left(8^{\text {th }}\right.$ and $9^{\text {th }}$ grades of basic school) and the three upper secondary classes, as recommended by the Bologna Process. Correspondingly, study programmes for basic school and upper secondary school teaching are separate. Teacher training for the basic school takes place at the former teacher training colleges, now University Colleges, and a position as a teacher in upper secondary school requires a university education as well as a minor practical-theoretical course. At present, intense negotiations are in progress concerning making

Note 8. Heads of upper secondary schools now have performance based pay contracts, which means that their salary is based on, among things, the pupils' marks, completion etc. The National Authority for Institutional Affairs under the Danish Ministry of Education recommends that the performance based pay scheme should also be extended to the other employees, including secondary teachers, like in the Finnish upper secondary school.

Note 9. Ministry of Education supervision plan 2006/2007

Note 10. Executive Order on quality development and performance assessment in upper secondary school education programmes (January 2005)

Note 11. Guidelines for Executive Order on quality development (January 2006) 


\section{Macrothink

Note 12. For example, the teaching guidelines for the smallest course in the Danish upper secondary school, "General Study Competences", which represents $10 \%$ of the study programme, is 176 pages long.

Note 13. For example, the teaching guidelines for the smallest course in the Danish upper secondary school, "General Study Competences", which represents $10 \%$ of the study programme, is 176 pages long. 